\title{
Kurumsal Kalitenin ve Makroekonomik Göstergelerin Finansal Piyasalara Etkisi: Gelişmekte Olan Piyasalar Üzerine Bir Araştırma
}

Esra Karpuz*
Nasıf Özkan** Öz

Bu çalışma, 2002-2017 yılları arasında Morgan Stanley Capital International Gelişmekte Olan Piyasalar Endeksi'nde (MSCIEF) yer alan borsaların gelişimini etkileyen kurumsal ve makroekonomik faktörleri saptamayı amaçlamaktadır. Bu bağlamda çalışmada, 25 gelişmekte olan piyasanın verileri panel veri modelleriyle analiz edilmektedir. Elde edilen bulgulara göre, kurumsal kalite değişkenlerinden politik istikrar ve şiddetsizlik ile ifade özgürlüğü ve hesap verilebilirlik değişkenlerinin, pay piyasalarının gelişimi üzerindeki etkisi pozitiftir. Benzer şekilde, makroekonomik değişkenlerden gayrisafi yurtiçi hasıla (GSYH) yıllık büyüme oranı, özel sektöre verilen yurtiçi krediler ve yurtiçi tasarruflar da pay piyasalarının gelişimini pozitif etkilemektedir.

Anahtar Kelimeler: Borsalar, Finansal gelişme, Gelişmekte olan ülkeler

JEL Sınıflandırması: E02, E44, G10, G30

\section{Abstract - The Effect of Institutional Quality and Macroeconomic Indicators on Financial Markets: A Research on the Emerging Markets}

This study aims to determine the institutional and macroeconomic factors affecting the development of the stock markets included in the Morgan Stanley Capital International Emerging Markets Index (MSCIEF) for 2002 to 2017. In this context, the data of 25 emerging markets are analyzed with panel data models in the study. According to the findings, political stability and the absence of violence and voice and accountability variables have positive effects on the development of those stock markets. Likewise, among macroeconomic variables, the annual gross domestic product (GDP) growth rate, domestic credits to the private sector, and domestic savings affect the development of those stock markets positively.

Keywords: Stock markets, Financial Development, Emerging Countries

JEL Classification: E02, E44, G10, G30

\footnotetext{
* Sorumlu Yazar, Kütahya Dumlupınar Üniversitesi, Kütahya Uygulamalı Bilimler Fakültesi, Finans ve Bankacılık Bölümü E-posta: esra.karpuz@dpu.edu.tr - ORCID ID: https://orcid.org/0000-0003-2765-4082

** Kütahya Dumlupınar Üniversitesi, Kütahya Uygulamalı Bilimler Fakültesi, Finans ve Bankacılık Bölümü -

E-posta: nasif.ozkan@dpu.edu.tr - ORCID ID: https://orcid.org/0000-0003-2612-6368
}

Makale Gönderim: 24.02.2021 Makale Kabul: 15.03.2021 DOI: http://dx.doi.org/10.46520/bddkdergisi.986671 


\section{Giriş}

Son yıllarda finansal piyasaların bir ülkenin ekonomik gelişme ve kalkınmasında oynadığı etkin rol, finansal piyasaların gelişimine etki eden faktörleri belirlemeye yönelik araştırmalara olan ilgiyi giderek arttırmaktadır. Dünya Bankası ve Uluslararası Para Fonu (International Monetary Fund - IMF) gibi kuruluşlar da finansal piyasalarda meydana gelen yükselişin likidite yaratma yoluyla, ülkelerin gelecek vaat eden bir ekonomiye sahip olmasına katkıda bulunabileceğini ifade etmektedir (IMF, 1996). Gelişmiş finansal piyasalar, ülkelerin olası finansal krizlere karşı hassasiyetlerini azaltmakta ve finansal sistemin bilgi, işlem ve izleme maliyetlerini düşürerek temel işlevi olan aracılık hizmetini en iyi şekilde yerine getirmesini sağlamaktadır (Cherif ve Gazdar, 2010). Ayrıca, finansal gelişim ile ekonomik büyüme ve kalkınma arasındaki etkileşimin karşılıklı olduğu söylenebilir. Finansal gelişim ekonomide üretken yatırımlara zemin hazırlayarak büyümeyi hızlandırırken, büyümedeki bu hız da finansal gelişimi desteklemektedir (Karaca, 2012).

Literatürde, 1990'lı yılların başlarına kadar gelişmiş bir finansal piyasanın varlığı ve bu piyasalar ile yatırımcılar arasında etkin bir mekanizmanın oluşturulması için ülkedeki makroekonomik koşulların uygunluğu üzerinde durulmaktadır. Ancak, 1990'lı yıllar ile birlikte finansal piyasalardaki gelişimin sadece makroekonomik koşullardan değil; bunun yanında ülkelerdeki politik, yasal ve kurumsal çerçevelerden de etkilendiği öne sürülmektedir (Thanh vd., 2016; Ajide, 2014; Law ve Azman-Saini, 2012; Asongu, 2012; Yartey, 2008). La Porta vd. (1997)'ye göre de bir ülkede adil bir hukuk sisteminin, kurumlarda güçlü bir yönetişim yapısının ve yatırımcıyı korumaya yönelik etkin mekanizmaların oluşturulması finansal piyasaların gelişimine önemli katkılar sağlamaktadır. Öte yandan literatürde, ülkelerdeki kurumsal yapının, finansal piyasaların gelişimi üzerinde etkili olmadığını ileri süren çalışmalar da bulunmaktadır (Cherif ve Gazdar, 2010; Narayan vd., 2015).

Gelişmekte olan ülkelerdeki finansal piyasaların gelişimini destekleyen politikaların uygulanabilirliğinin arttırıması ile kurumsal yapının ve makroekonomik koşulların iyileştirilmesi bu ülkelerin finansal piyasalarının gelişimine olumlu katkıda bulunacaktır. Bu bağlamda, gelişmekte olan ülkelerdeki politika yapıcıların, finansal piyasaların gelişimini etkileyen ve bu ülkeler arasından fark yaratarak sıyrılmayı sağlayacak temel faktörlerin farkına varmaları ve bu gelişimi hızlandıracak makroekonomik ve kurumsal koşulları oluşturmaları önem arz etmektedir. Literatürde, finansal piyasaların gelişimine etki eden faktörleri inceleyen birçok çalışma bulunmaktadır. Bu çalışmalardan finansal piyasaların gelişimine etki eden kurumsal kalite göstergelerini inceleyenler (Lombardo ve Pagano, 2000; Asongu, 2012; Narayan vd., 2015; Winful, 2016; Bo- 
adi ve Amegbe, 2017; Ayaydın vd., 2019); makroekonomik göstergelerin etkisini inceleyen çalışmalara (Garcia ve Liu, 1999; Claessens vd., 2001; Yartey, 2008; Law ve Habibullah, 2009; Kemboi ve Tarus, 2012; Shahbaz vd., 2015; Raza vd., 2015; Acquah-Sam, 2016) göre nispeten daha azdır. Literatürdeki araştırmalarda elde edilen bulgularda kesin bir görüş birliğinin sağlanamaması, bu faktörlerin etkilerinin araştıııma gerekliliğini ortaya çıkarmaktadır.

Bu çalışmanın, gelişmekte olan ülkelerdeki finansal piyasaların gelişiminin makroekonomik ve kurumsal belirleyicilerini birlikte ele alarak geniş bir veri setini içermesi ve çok yönlü bir araştırma sunmayı hedeflemesiyle literatürde önemli bir yer edineceği düşünülmektedir. Bunun yanı sıra, literatürde kurumsal kalite yapısının finansal piyasalara etkisini firma düzeyindeki kurumsal yönetişim göstergeleriyle inceleyen çalışmalar oldukça fazla olmasına karşın, ülke düzeyindeki kurumsal yapının finansal piyasalara etkisini inceleyen çalışmaların sayısı da görece daha azdır. Çalışmanın literatürdeki bu boşluğu doldurması da beklenmektedir. Bu nedenle çalışmada, ülke düzeyindeki kurumsal kalite ve makroekonomik faktörlerin, Morgan Stanley Capital International Gelişmekte Olan Piyasalar Endeksi'nde (MSCIEF) yer alan ülkelerin finansal piyasalarının gelişimi üzerindeki etkisi birlikte ortaya konulmakta ve böylece literatüre önemli bir katkı sunulmaktadır. Çalışmada elde edilen bulgular, gelişmekte olan ülkelerdeki politik istikrarsızlığın ve şiddetin azaltılmasının, finansal piyasaların gelişimine olumlu bir etkisinin olduğunu göstermektedir. Ayrıca, gelişmekte olan ülke vatandaşlarının ifade özgürlüğünün sağlanmasının ve hükümetlerin faaliyetlerinde daha hesap verebilir hale gelmesinin de bu ülkelerin finansal piyasalarındaki gelişmeleri pozitif etkilediği görülmektedir. Çalışmada finansal piyasaların gelişimine etki eden en önemli makroekonomik faktörün ise, yurtiçi tasarruflar olduğu sonucuna ulaşılmaktadır. Buradan hareketle, gelişmekte olan ülkelerde yatııımların en önemli finansman kaynaklarından biri olan yurtiçi tasarruflarda meydana gelen artışın, finansal piyasaların gelişimine öncülük ettiğini söylemek mümkündür. Çalışmanın bir diğer bulgusu ise, finansal derinliğin banka temelli ölçütü olan özel sektöre verilen kredilerdeki artışın, finansal piyasaların gelişimi üzerinde pozitif etkili olduğudur.

Çalışma beş bölümden oluşmaktadır. Giriş bölümünü takip eden ikinci bölümde, finansal piyasaların gelişimine etki eden faktörleri araşııan literatür çalışmalarına yer verilmektedir. Üçüncü bölümde, çalışmanın veri seti, değişkenleri ve metodolojisi açıklamaktadır. Dördüncü bölümde, çalışmada elde edilen ampirik bulgular, literatürdeki diğer çalışmaların bulgularıyla karşılaştırılarak sunulmaktadır. Çalışmanın son bölümünde ise, çalışma sonuçları bir bütünlük çerçevesinde özetlenerek tartışılmakta ve çalışmanın kısıtlarına değinilerek gelecekte yapılacak çalışmalar için öneriler verilmektedir. 


\section{Literatür Taraması}

Literatürde makroekonomik faktörler ile kurumsal kalitenin finansal piyasaların gelişimine etkisini inceleyen birçok çalışma bulunmaktadır. Çalışmalardan bazıları makroekonomik faktörlerin, bazıları kurumsal kalitenin, diğerleri ise hem makroekonomik faktörlerin hem de kurumsal kalitenin finansal piyasalara etkisini araştırmaktadır. Bu çalışmalar, daha çok gelişmiş ve gelişmekte olan ülkeler gibi ülke gruplarını veri setlerine dahil etmektedir. Lombardo ve Pagano (2000), kurumsal kalite göstergeleriyle pay piyasaları arasındaki ilişkiyi araştıran ilk çalışmalardandır. Araştırmacılar, 21 gelişmekte olan ülkede toplam pay piyasası getirilerinin, yargı etkinliği ve hukukun üstünlüğü gibi kurumsal kalite göstergelerinden pozitif yönde etkilendiğini vurgulamaktadır.

Asongu (2012), Dünya Bankası tarafından kurumsal kaliteyi temsilen yayımlanan yolsuzluğun kontrolü, hükümetin etkinliği, ifade özgürlüğü ve hesap verilebilirlik, politik istikrar, düzenleyici kalitesi ve hukukun üstünlüğünü değişkenlerinin, 14 Afrika ülkesinin pay piyasaları üzerindeki etkisini araştırmaktadır. Çalışmada, 1990-2010 dönemi için dört ayrı panel veri modeli kullanılmaktadır. Çalışmanın bağımlı değişkenleri; piyasa kapitalizasyonu, borsa toplam işlem değeri, borsa devir hızı ve kişi başına kayıtlı şirket sayısıdır. Analiz sonuçları, pay piyasasının gelişimini temsil eden bağımlı değişkenler ile tüm kurumsal kalite göstergeleri arasında istatistiksel olarak anlamlı pozitif bir ilişki olduğunu göstermektedir. Bu sonuçlara göre Asongu (2012), daha iyi kurumsal kaliteye sahip ülkelerin piyasa kapitalizasyonunun, borsa toplam işlem değerini, borsa devir hızını ve kişi başına kayıtlı şirket sayısını artıracağını ileri sürmektedir.

Winful vd. (2016), gelişmekte olan 41 ülkede kurumsal kalitenin, pay piyasaları gelişimi üzerindeki etkisini 1996-2011 yılları için dinamik panel veri analizi yöntemiyle incelemektedir. Araştırmacılar, 7 ayrı model oluşturarak, her bir kurumsal kalite değişkenini analize tek tek dahil etmektedir. Bu yöntemle elde edilen bulgular, her bir kurumsal kalite göstergesinin gelişmekte olan ülkelerin pay piyasalarının gelişimi üzerindeki etkisinin istatiksel olarak anlamlı ve pozitif olduğunu göstermektedir. Diğer bir ifade ile ülkelerin kurumsal kalite düzeyleri arttıkça borsa performanslarının da geliştiği ifade edilmektedir. Ayaydın vd. (2019) da 2002-2015 dönemi yıllık veri setlerini kullanarak, kurumsal kalite göstergeleri ile pay piyasaları gelişimi arasındaki ilişkiyi yine dinamik panel veri modeliyle analiz etmektedir. Çalışmanın örneklemini, 26'sı gelişmiş ve 34'ü gelişmekte olan 60 ülke oluşturmaktadır. Araştırmacılar, Winful vd. (2016)'nın çalışmasında olduğu gibi kurumsal kalite göstergeleri ile 7 
ayrı model oluşturmakta ve benzer sonuçlar elde ederek her bir kurumsal kalite göstergesinin ülkelerin pay piyasalarının gelişimi üzerindeki etkisinin istatiksel olarak anlamlı ve pozitif olduğunu vurgulamaktadır. Çalışmada elde edilen diğer bir bulgu ise, kurumsal kalite göstergelerinin gelişmiş ülkelere kıyasla gelişmekte olan ülkelerin piyasa gelişimi üzerinde daha güçlü bir etkisinin olmasıdır. Khan vd. (2019) da benzer şekilde sözü edilen kurumsal kalite göstergelerinden ayrı modeller oluşturarak finansal gelişim üzerindeki etkiyi yükselen ve büyümenin öncüsü ekonomiler (Emerging and Growth-Leading Economies - EAGLEs) için araştırmaktadır. Araştırmacılar Winful vd. (2016) ve Ayaydın vd. (2019)'un çalışmalarından farklı olarak düzenleyici kalitesi ve yolsuzluğun kontrolü göstergelerinin finansal gelişim üzerindeki etkisini istatiksel olarak anlamsız bulurken, diğer kurumsal kalite göstergelerinin çalışmalarla benzer şekilde pozitif etkili olduğunu ifade etmektedir.

Narayan vd. (2015), Uluslararası Ülke Risk Kılavuzu (International Country Risk Guide - ICRG) tarafından yayımlanan kurumsal kalite göstergelerini kullandıkları çaışmalarında, bu göstergelerin pay piyasalarının getirilerini tahmin etmedeki rolünü araştırmaktadır. Çalışmanın örneklemini, araştırmacıların kredi derecelendirme kuruluşu notlarına göre AA- ve üzeri güçlü ülkeler ile A ve altı notlar alan zayıf ülkeler olmak üzere 2 gruba ayırdıkları 38 ülke oluşturmaktadır. En uygun genelleştirilmiş en küçük kareler (Feasible Generalized Least Square - FGLS) tekniği kullanılarak elde edilen analiz sonuçlarına göre, derecelendirme notu zayıf olan ülkelerde kurumsal kalite göstergeleri pay getirilerini tahmin etmede etkili bir faktör iken, kredi derecelendirme notu yüksek olan ülkelerde kurumsal kalite göstergeleri pay getirilerini tahmin etmede etkili değildir. Boadi ve Amegbe (2017) de benzer şekilde ICRG tarafından kredi derecelendirme notuna göre sınıflandırılan düşük, orta ve yüksek gelirli 23 ülkede 1996-2014 yılları arasında kurumsal kalitenin pay piyasalarının getirileri üzerindeki etkisini araştırmaktadır. Araştırma bulgularına göre, yüksek gelirli ülkelerin piyasa getirileri üzerinde ifade özgürlüğü ve hesap verilebilirlik ile hukukun üstünlüğünün negatif etkisi bulunurken, politik istikrar ve hükümetin etkinliği pozitif etkili bulunmuştur. Orta gelirli ülkelerin piyasa getirilerine etki eden faktörlere ilişkin sonuçlara bakıldığında, sadece hukukun üstünlüğü ve yolsuzluğun kontrolünün etkili olduğu ve bu etkinin pozitif olduğu görülmektedir. Düşük gelirli ülkelerde ise, ifade özgürlüğü ve hesap verilebilirlik ile hükümetin etkinliğinin piyasa getirilerinin üzerindeki etkisi negatif, düzenleyici kalitesi ve hukukun üstünlüğünün etkisi ise pozitiftir. Narayan vd. (2015)'in çalışmasında olduğu gibi Boadi ve Amegbe (2017) de ülkeleri kredi derecelendirme notuna göre sınıflandırdığında ise, kurumsal kalitenin piyasa getirileri üzerindeki etkileri farklılık göstermektedir. 
Ajide (2014), Nijerya pay piyasasında 1996-2010 yılları arasında kurumsal kalitenin ve seçili makroekonomik faktörlerin pay piyasası performansına olası etkilerini incelemektedir. Çalışmada nedensellik ilişkisi, gecikmesi dağıtılmış otoregresif sınır testi (ARDL- Autoregressive Distributed Lag Bound Test) yaklaşımı ile sınanmaktadır. Çalışmada pay piyasası performansı toplam payların fiyat endeksi, piyasa kapitalizasyonu ve işlem gören payların toplam değeri olmak üzere üç farklı gösterge ile ölçülmektedir. Analizler sonucunda, yolsuzluğun kontrolü ve hükümetin etkinliğinin pay piyasası performansına olumlu etkisi olduğu saptanırken, politik istikrarsızlık göstergesinin pay piyasası performansını zayıflattığı belirtilmektedir. Diğer taraftan çalışmada, hukukun üstünlüğü ile ifade özgürlüğü ve hesap verilebilirlik göstergelerinin pay piyasası performansı üzerindeki etkisinin anlamsız olduğu belirtilmektedir. Gelişmekte olan ülkeler ve Vietnam pay piyasalarının gelişimini etkileyen faktörleri araştıran Thanh vd. (2016) de 36 ülkeye ilişkin 2003-2014 dönemi veri setini genelleştirilmiş momentler yöntemini (Generalized Method of Moments - GMM) kullanarak analiz etmektedir. Araştırmada, hükümetin etkinliği ve hukukun üstünlüğü gibi kurumsal göstergelerin gelişmekte olan ülkelerin pay piyasalarının gelişimi üzerindeki etkisi pozitifken, yolsuzluğun kontrolü ve politik istikrar göstergelerinin etkisi negatiftir. Diğer kurumsal kalite göstergelerinden olan düzenleyici kalitesi ile ifade özgürlüğü ve hesap verilebilirliğin gelişmekte olan ülkelerin pay piyasasının gelişimi üzerindeki etkisi ise istatiksel olarak anlamsız bulunmuştur. Araştırmanın makroekonomik değişkenlerinden ekonomik büyüme, yurtiçi krediler ve piyasa likiditeleri gelişmekte olan ülkelerin pay piyasasına etkileri pozitif bulunurken, enflasyon negatif etkili, yurtiçi yatırımlar ile doğrudan yabancı yatırımlar ise etkisiz bulunmuştur. Çalışmada incelenen Vietnam pay piyasası içinse, elde edilen sonuçlar farklılık göstermektedir. Ajide (2014)'ün Nijerya piyasasında elde ettiği bulgulardan farklı olarak yolsuzluğun kontrolü, hükümetin etkinliği, politik istikrar, düzenleyici kalitesi, hukukun üstünlüğü, ifade özgürlüğü ve hesap verebilirlik olmak üzere tüm kurumsal göstergelerin Vietnam borsası üzerinde istatistiksel olarak anlamlı ve pozitif yönde etkisinin olduğu görülmektedir. Bu bulguların yanı sıra, gelişmekte olan ülkeler üzerindeki etkilerinden farklı olarak, araştırmanın makroekonomik değişkenlerinin Vietnam pay piyasası üzerindeki etkisi istatiksel olarak anlamlı ve negatiftir.

Umar ve Nayan (2018), Dünya Bankası tarafından yayımlanan kurumsal kalite göstergelerinden düzenleyici kalitesinin 12 Afrika ülkesindeki pay piyasalarının gelişimine olan etkisini 1996-2016 yılları için araştırmaktadır. Çalışmada analiz yöntemi olarak Pesaran vd. (1999) tarafından geliş̧irilen havuzlanmış ortalama grup (Pooled Mean Group - PMG) tahmincisi kullanılmaktadır. Bulgulara göre, düzenleyici kalitesiPiyasalar Üzerine Bir Araştırma”, BDDK Bankacılık ve Finansal Piyasalar Dergisi, 15, (1), 2021, 147-173 
nin Afrika ülkelerindeki piyasaların gelişimi üzerindeki etkisi istatiksel olarak anlamlı ve pozitiftir. Bulgulara ek olarak, çalışmanın kontrol değişkenleri olan makroekonomik faktörlerden GSYH büyüklüğünün pay piyasalarının gelişimini pozitif, döviz kuru ise negatif etkilemektedir.

Ülkemizde de kurumsal kalite düzeyinin ülkedeki pay piyasası gelişimine etkisini inceleyen çalışmalar bulunmaktadır. Şahin ve Temelli (2018), Türkiye ve Asya - Pasifik Ekonomik İşbirliği ülkeleri (Asia - Pacific Economic Cooperation - APEC) pay piyasalarının gelişimini etkileyen kurumsal ve makroekonomik faktörleri 1995-2015 dönemi için analiz etmektedir. Araştırmacıların kullandığı kurumsal kalite faktörleri literatürden farklılık göstermektedir. Çalışmada kurumsal kaliteyi temsilen Uluslararası Şeffaflık Örgütü tarafından oluşturulan yolsuzluk algılama endeksi ile Heritage Vakfı'nın yayınladığı ekonomik özgürlük endeksi kullanılmaktadır. Bulgular, analize dahil edilen ülkelerde yolsuzluk azaldıkça pay piyasası gelişiminin arttığını, ekonomik özgürlük endeksinin ise, pay piyasası gelişimi üzerinde istatiksel olarak anlamlı bir etkisinin olmadığını göstermektedir. Güvercin ve Gök (2019) ise hukukun üstünlüğü ve düzenleyici kalitesi kurumsal kalite göstergelerinin AB-15 ülkelerinin borsa ve bankacılık gelişimleri üzerindeki etkisini 1996-2012 yılları için araştırmaktadır. Araştırmacılar elde ettikleri bulgularda her iki göstergenin de ülkelerin borsa ve bankacılık gelişimini arttırdığını ifade etmektedir. İltaş ve Üçler (2019) de on farklı yönetişim faktöründen ${ }^{1}$ temel bileşenler analizi ile elde ettiği kurumsal kalite endeksi ile finansal risk seviyesinin BIST 100, BiST Sınai ve BIST Mali endeksleri üzerindeki etkisini araştırmaktadır. Araştırmacılar çalışmalarında, 1991-2014 dönemini, Maki (2012) tarafından geliştirilen çoklu yapısal kırılmalı eşbütünleşme testi ve dinamik en küçük kareler (DOLS) tekniklerini kullanarak analiz etmektedir. Çalışmanın sonuçları, kurumsal kalite endeksinin BIST 100 ve BisT Sınai endeksleri ile uzun dönemde birlikte hareket ettiğini göstermektedir. Dinamik en küçük kareler analizinden elde edilen bulgulara göre ise, kurumsal kalite düzeyinin iyileşmesi BIST 100 ve BIST Sınai endeksleri üzerinde olumlu etkiye neden olurken, BiST Mali endeksi üzerinde etkisi bulunmamaktır.

Garcia ve Liu (1999), makroekonomik faktörlerin pay piyasalarının gelişimi üzerindeki etkisini inceleyen literatürdeki ilk çalışmalardandır. Çalışmada ekonomik büyüme oranı, piyasa likiditesi, yurtiçi tasarruflar, yatırımlar ve krediler ile enflasyon oranının 15 Latin Amerika ve Doğu Asya ülkesinde pay piyasalarının gelişimi üzerin-

1 Uluslararası Ülke Risk Kılavuzu (ICRG) tarafından yayımlanan bu faktörler bürokratik kalite, yolsuzluk, demokratik hesap verilebilirlik, etnik gerginlik, dış çatışma, hükümet istikrarı, iç çatışma, politik risk, kanun ve düzen ile yatırım profilidir.

E. Karpuz, N. Özkan, "Kurumsal Kalitenin ve Makroekonomik Göstergelerin Finansal Piyasalara Etkisi: Gelişmekte Olan Piyasalar Üzerine Bir Araştırma”, BDDK Bankacılık ve Finansal Piyasalar Dergisi, 15, (1), 2021, 147-173 
deki etkisi 1980-1995 yılları için araştırılmaktadır. Bulgular, enflasyon oranının pay piyasası gelişimi üzerindeki etkisinin negatif, fakat istatiksel olarak anlamsız olduğunu göstermektedir. Öte yandan, çalışmanın diğer makroekonomik değişkenlerinin pay piyasalarının gelişimi üzerindeki etkisi pozitif bulunmuştur. Benzer çalışmalardan olan Claessens vd. (2001) de farklı gelir gruplarına tabi olan 77 ülkenin 1975-2000 yılları arasındaki ekonomik büyüme, enflasyon oranı ve doğrudan yabancı yatırımları ülkelerin pay piyasalarının gelişimi üzerindeki etkisini incelemeyi amaçlamaktadır. Araştırmacılar Garcia ve Liu (1999) ile uyumlu olarak ekonomik büyüme ve yatırımların piyasa gelişimi üzerindeki etkisinin olumlu olduğunu savunmaktadır. Ancak çalışmada, enflasyonun pay piyasalarının gelişimi üzerindeki etkisini negatif ve istatiksel olarak anlamlı olduğu belirtilmektedir.

Acquah-Sam (2016), Gana pay piyasalarının gelişimine etki eden makroekonomik faktörleri 1991-2011 dönemi için araştırmaktadır. Analizinde yapısal eşitlik modeli kullanılan çalışmada, ülke gelirinde ve gayri safi sabit sermayede meydana gelen artışın, Gana pay piyasalarının gelişimine katkıda bulunduğu ifade edilmektedir. Ülkedeki düşük faiz oranları ve enflasyon ise yatırımcıların pay piyasalarına katılımını teşvik etme yoluyla piyasa gelişimini arttırmaktadır. Öte yandan çalışmanın sonuçları, ülkedeki doğrudan yabancı yatırımların Gana pay piyasalarının gelişimini etkilemediğini göstermektedir. Kemboi ve Tarus (2012) de benzer şekilde makroekonomik faktörler ile pay piyasaları arasındaki ilişkiyi Kenya Nairobi pay piyasası için araştırmaktadır. Çalışmanın makroekonomik değişkenlerini kişi başına düşen GSYH büyüme oranı, reel faiz oranı, enflasyon oranı, para arzı, Nairobi pay piyasasında işlem gören payların toplam değeri ve piyasa likiditesi oluşturmaktadır. Değişkenler arasındaki ilişki gecikmesi dağıtılmış otoregresif sınır testi (ARDL - Autoregressive Distributed Lag Bound Test) ve Granger nedensellik testi yardımıyla analiz edilmektedir. Analiz sonuçları, piyasa likiditesi, GSYH büyüme oranı ve bankacılık sektörünün piyasa gelişimi üzerinde olumlu etkisi olduğunu göstermektedir. Ancak çalışmada, Acquah-Sam (2016)'nın Gana pay piyasalarında elde ettiği sonuçların aksine, Kenya pay piyasalarının gelişiminde enflasyon ve faiz oranları etkisiz bulunmuştur.

Pakistan pay piyasasının gelişiminin makroekonomik belirleyicilerini 1974-2010 yılları için araştıran Shahbaz vd. (2015), çalışmalarında ARDL sınır testi ve Granger nedensellik yaklaşımlarından faydalanmaktadır. Çalışmanın makroekonomik değişkenlerini ekonomik büyüme, finansal gelişme, portföy ve yabancı yatırımlar, enflasyon ve dış ticarete açıklık oranları oluşturmaktadır. ARDL sınır testi sonuçlarına göre, makroekonomik değişkenler ve Pakistan pay piyasasının gelişimi arasında uzun dönemli eş bütünleşme ilişkisi bulunmaktadır. Bulgulara göre, ekonomik büyüme, Piyasalar Üzerine Bir Araştırma”, BDDK Bankacılık ve Finansal Piyasalar Dergisi, 15, (1), 2021, 147-173 
enflasyon, finansal gelişme ve yatırımlar Pakistan pay piyasalarının gelişimini arttırmakta, ancak dış ticarete açıklık oranı pay piyasaların gelişimini zayıflatmaktadır. Granger nedensellik analizinden elde edilen sonuçlar ise, Pakistan pay piyasasının gelişiminden çalışmanın makroekonomik değişkenlerine doğru bir nedensellik ilişkisi olduğunu göstermektedir. Raza vd. (2015) de yine Pakistan pay piyasalarının gelişiminde döviz kuru, enflasyon, yurtiçi tasarruflar ve doğrudan yabancı yatırımların rolünü 1988-2009 dönemi için araştırmaktadır. Araştırma sonuçlarına göre, yurtiçi tasarruflar ile doğrudan yabancı yatırımlarda meydana gelen bir artış Pakistan pay piyasalarının gelişimini arttırırken, döviz kurunda meydana gelen oynaklıklar ise pay piyasalarının gelişimini önemli düzeyde azaltmaktadır. Çalışmada Shahbaz vd. (2015)'in bulgularına zıt olarak, enflasyon oranlarının Pakistan pay piyasalarının gelişimi üzerinde istatiksel olarak anlamlı bir etkisinin olmadığı saptanmıştır.

Gelişmekte olan 42 ülkede yolsuzluk, bankacılık sektörünün gelişimi ve bir takım makroekonomik faktörlerin finansal piyasaların gelişimine etkisini ortaya koymayı hedefleyen Ayaydın ve Baltacı (2013), 1996-2011 yıllarına ait veri setlerini kullanmaktadır. Panel veri analizinin uygulandığı çalışmada, Uluslararası Şeffaflık Örgütü tarafından yayımlanan Yolsuzluk Algılama Endeksi (Corruption Perception Index CPI) yolsuzluk seviyesinin piyasa gelişimiyle istatiksel olarak anlamlı ve negatif yönlü bir ilişki olduğu belirtilmektedir. Çalışmada, ülkelerin bankacılık sisteminin gelişimini temsilen ise, bankacılık sektörü sermayeleri ve özel sektöre verilen krediler kullanımaktadır. Bulgulara göre, bankacılık sektöründeki sermaye payının artması ve özel sektöre verilen kredilerdeki artış piyasa gelişimi üzerinde olumlu etkiye sahiptir. Bunun yanı sıra araştırmacılar, ülkelerdeki yolsuzluğun yıkıcı etkilerinin, bankacılık sistemindeki gelişmenin olumlu etkilerinden daha önemli olduğunu vurgulamaktadır. Çalışmanın makroekonomik faktörlerinden elde edilen bulgular, enflasyon ve reel faiz oranlarının piyasa gelişimini olumsuz etkilediği, GSYH büyüme oranı, M2 para arzı, yurtiçi tasarruflar ve yabancı yatırımların ise piyasa gelişimine katkıda bulunduğu şeklindedir.

Yartey (2008), pay piyasası gelişimini etkileyen makroekonomik faktörler ile kurumsal kalite göstergelerini araştıran bir diğer çalışmadır. 42 gelişmekte olan ülkede 1990-2004 yıllarına ait veri setini kullanan çalışmada panel veri analizi kullanılmaktadır. Araştırma bulgularına göre özel sektöre verilen krediler, piyasa likiditesi, yurtiçi yatırımlar ve kişi başına düşen GSYH makroekonomik değişkenleri pay piyasalarının gelişimi üzerinde pozitif etkilidir. Bunun yanında, reel faiz oranları, enflasyon oranları ve yurtiçi tasarruflarının ise pay piyasalarının gelişimi üzerinde etkisi bulunmamaktadır. Araştırmanın kurumsal kalite değişkenlerinden politik risk, hukuk ve düzen, 
bürokratik kalite ve demokratik hesap verilebilirlik pay piyasalarının gelişimini pozitif yönde etkilerken, yolsuzluk değişkeninin etkisi negatif ancak istatiksel olarak anlamsızdır. Cherif ve Gazdar (2010), 1990-2007 döneminde 14 Ortadoğu ve Kuzey Afrika (Middle East and North Africa - MENA) ülkelerinin pay piyasalarının gelişimini etkileyen makroekonomik ve kurumsal faktörleri belirlemeyi amaçlayan çalışmalarında panel veri analizini ve enstrümantal değişken tekniklerini kullanmaktadır. Çalışmada, kurumsal kaliteyi hukuk ve düzen, bürokrasi kalitesi, demokratik hesap verebilirlik ve yolsuzluk göstergeleri temsil etmektedir. Araştırmacıların bulguları, Yartey (2008)'in bulgularının aksine, kurumsal kalitenin pay piyasalarının gelişiminde istatiksel olarak anlamlı bir etkisinin olmadığını göstermektedir. Diğer bir ifade ile kurumsal kalite göstergeleri, MENA ülkelerindeki pay piyasalarının gelişimine etki eden anlamlı faktörlerden değildir. Bunun yanı sıra, reel GSYH, piyasa likiditesi ve yurtiçi yatııımların piyasa gelişimi üzerindeki etkisi pozitif iken, enflasyon oranı ile yurtiçi tasarrufların piyasa gelişimi üzerindeki etkisi istatiksel olarak anlamsız bulunmuştur. Bu bulgular ise, Yartey (2008)'in çalısmasını destekler niteliktedir.

Law ve Habibullah (2009) ise, 1980-2001 dönemi için makroekonomik faktörlerin ve kurumsal kalitenin Avrupa, Doğu Asya ve Latin Amerika'dan seçilen 27 ülkenin finansal piyasalarına etkisini incelemektedir. Çalışmanın makroekonomik değişkenlerini kişi başına düşen reel GSYH, finansal serbestleşme endeksi ve ticarete açıklık oluştururken, kurumsal kaliteyi Uluslararası Ülke Risk Kılavuzu (International Country Risk Guide - ICRG) tarafından yayımlanan yolsuzluk, bürokratik kalite, hukukun üstünlüğü, devletin sözleşmeleri tanımama ve el koyma riski göstergelerinin toplanmasıyla elde edilen endeks oluşturmaktadır. Dinamik panel veri yönteminin kullanıldığı araştırmanın sonuçlarına göre, ilgili 27 ülkenin finansal piyasalarının gelişiminde kurumsal kalite endeksinin ve makroekonomik faktörlerin istatistiksel olarak anlamlı etkisi bulunmaktadır. Law ve Azman-Saini (2012), çalışmalarında kurumsal kalitenin finansal piyasaların gelişimi üzerindeki etkisini 1996-2004 yılları arasında 51 gelişmekte olan ülke için araştırmaktadır. Çalışmada, finansal gelişim ölçüsü olarak daha önceki çalışmalarda olduğu gibi sermaye piyasası kapitalizasyonu ve özel sektör kredileri kullanılmaktadır. Çalışmada kurumsal kalite ise Law ve Habibullah (2009)'un çalışmasına benzer olarak, yolsuzluk, hukukun üstünlüğü, hükümetin etkinliği, ifade özgürlüğü, düzenleyici kalitesi ve politik istikrar göstergelerinin toplanmasıyla elde edilen endeksler ile ifade edilmektedir. Dinamik panel veri analizi sonuçları, her iki kurum tarafından yayımlanan kurumsal kalite endeksinin ülkelerin sermaye piyasası kapitalizasyonu ve özel sektör kredileri üzerinde pozitif etkisinin olduğunu gösterPiyasalar Üzerine Bir Araştırma”, BDDK Bankacılık ve Finansal Piyasalar Dergisi, 15, (1), 2021, 147-173 
mektedir. Aduda vd. (2012) de çalışmalarında 2005-2009 yılları arasında Nairobi pay piyasası üzerinde etkili olan makroekonomik ve kurumsal faktörleri araştırmaktadır. Çalışmada, kurumsal kaliteyi bürokratik kalite, hukuk ve düzen, yolsuzluk ve demokratik hesap verilebilirlik göstergeleri ile oluşturulan politik risk endeksi temsil etmektedir. Çalışmada, Nairobi pay piyasasının gelişmesinde borsa likiditesi, kişi başına gelir, yurtiçi tasarruflar ve özel sektöre verilen kredilerin istatiksel olarak anlamlı ve pozitif etkisi olduğu belirtilmektedir. Politik risk endeksi ile ifade edilen kurumsal kalitenin pay piyasası gelişimi üzerindeki etkisi ise Law ve Habibullah (2009) ve Law ve Azman-Saini (2012)'nin oluşturdukları endeksin aksine negatiftir. Öte yandan çalışmada, enflasyon ve özel sermaye akımları ile pay piyasasının gelişimi arasında istatistiksel olarak anlamlı bir ilişki olmadığı vurgulanmaktadır.

\section{Veri ve Metodoloji}

Bu çalışmada, Haziran 2020 itibarıyla MSCI Gelişmekte Olan Piyasalar Endeksi'nde $(\mathrm{MSCIEF})^{2}$ yer alan 25 ülkenin ${ }^{3}$ 2002-2017 yılları arasındaki verileri kullanılmaktadır. Çalışmanın veri döneminin belirlenmesinde, kurumsal kaliteyi temsil eden yönetişim göstergelerine 2002 yılından itibaren ulaşılabilmesi rol oynamaktadır . Veriler, Dünya Bankası ve Uluslararası Para Fonu (International Monetary Fund - IMF) veri tabanından elde edilmiştir.

Çalışmada kullanılan değişkenlerin ampirik tanımları Tablo 1'de verilmektedir. Çalışmanın bağımlı değişkeni piyasa kapitalizasyonudur (PK). PK, birçok çalışmada piyasaların gelişimini temsilen kullanılan temel ölçülerden biridir (Garcia ve Liu, 1999; Asongu, 2012; Law ve Azman-Saini, 2012). PK, borsada işlem gören payların toplam değerinin gayri safi yurtiçi hasılaya (GSYH) bölünmesiyle elde edilmektedir. Çalışmada kullanılan bağımsız değişkenler, kurumsal kalite değişkenleri (KKD) ve makroekonomik değişkenler olmak üzere ikiye ayrılmaktadır. Kurumsal kalite değişkenlerini, yolsuzluğun kontrolü (YK), hükümetin etkinliği (HE), politik istikrar ve şiddetsizlik (PI), düzenleyici kalitesi (DK), hukukun üstünlüğü (HU), ifade özgürlüğü ve hesap verilebilirlik $(\mathrm{IOH})$ olmak üzere altı temel gösterge temsil etmektedir. Ayrıca, temel bileşenler analizi yardımıyla bu altı gösterge kullanılarak yazarlar tarafından oluştu-

2 MSCIEF, Morgan Stanley Capital International yatııım araştırma firması tarafından gelişmekte olan pay piyasalarının performansını ölçmek amacıyla 1988 yılından beri hesaplanmakta olan bir endekstir. 30 Haziran 2020 tarihi itibarıla endekste ağırlığı en yüksek olan ilk üç ülke Çin $(\% 40,95)$, Tayvan $(\% 12,28)$ ve Güney Kore'dir $(\% 11,61)$ (https:// www.msci.com/emerging-markets).

3 MSCIEF'te 30 Haziran 2020 tarihi itibariyle 26 ülke bulunmaktadır. Bu ülkeler: Arjantin, Brezilya, Şili, Kolombiya, Meksika, Peru, Çek Cumhuriyeti, Mısır, Yunanistan, Macaristan, Polonya, Katar, Rusya, Suudi Arabistan, Güney Afrika, Birleşik Arap Emirlikleri, Çin, Hindistan, Endonezya, Kore, Malezya, Pakistan, Filipinler, Tayvan, Tayland ve Türkiye'dir. Dünya Bankası'nda Tayvan'a ilişkin verilerin sınırlı̆̆ı nedeniyle bu ülke araştırmaya dahil edilememiştir.

4 Analizin yapıldığı dönemde bağımlı ve bağımsız değişkenlerin 2017 yılına kadar ki verilerine ulaşılabilmiştir. 
rulan kurumsal kalite endeksi (KK) de çalışmanın diğer bir bağımsız değişkenidir 5 . Literatürde yapılan diğer çalışmalara (Yartey, 2008; Cherif ve Gazdar, 2010; Aduda vd., 2012; Thanh vd., 2016) paralel olarak büyüme oran (BO), yurtiçi krediler (KRD), doğrudan yabancı yatırımlar (DYY), yurtiçi tasarruflar (YIT), yurtiçi yatırımlar (YIY) ve enflasyon oranı (TUFE) gibi göstergeler de makroekonomik değişkenler olarak analize dahil edilmektedir 6 .

\section{Tablo 1. Analizde kullanılan değişkenler}

\begin{tabular}{lll}
\hline Değişken & Ampirik Tanım & Sembol \\
\hline Piyasa Kapitalizasyonu & Borsada işlem gören payların toplam değeri / GSYH & PK \\
\hline
\end{tabular}

\section{Kurumsal Kalite Değişkenleri (KKD)}

Yolsuzluğun Kontrolü

Hükümetin Etkinliği

Politik İstikrar ve Şiddetsizlik

Düzenleyici Kalitesi

Hukukun Üstünlüğü

ifade Özgürlüğü ve Hesap

Verilebilirlik

Kurumsal Kalite
Kamuya ait gücün özel kazançlar için kullanımını önleme

YK

Kamu hizmetlerinin kalitesi ve hükümetin politikalara bağlılı̆ı

Politik istikrarı bozan terör vb. şiddet olaylarının yokluğu

Hükümetin özel sektöre sağladığı teşvik edici politikaların kalitesi

Toplum ve kurumların yasalara uyma ölçüsü ve mahkemelerin kalitesi

Vatandaşların hükümeti seçme özgürlüğü ve ifade özgürlüğü $\quad \mathrm{IOH}$ Altı kurumsal kalite değişkeni ile oluşturulan kurumsal kalite endeksi

HE

$\mathrm{PI}$

DK

HU

KK

\section{Makroekonomik Değişkenler}

\begin{tabular}{lll}
\hline Büyüme Oranı & GSYH yıllık büyüme oranı & BO \\
Yurtiçi Krediler & Özel sektöre verilen yurtiçi krediler / GSYH & KRD \\
Doğrudan Yabancı Yatırımlar & Net doğrudan yabancı yatırım girişleri / GSYH & DYY \\
Yurtiçi Yatırımlar & Gayri safi sermaye oluşumu / GSYH & YIY \\
Yurtiçi Tasarruflar & (GSYH-Nihai tüketim harcamaları) / GSYH & YIT \\
Enflasyon Oranı & Tüketici fiyat endeksindeki yıllık yüzde değişim oranı & TUFE \\
\hline
\end{tabular}

Kurumsal kalite ve makroekonomik değişkenlerin pay piyasası gelişimine etkisi, çok sayıda yatay kesit ve zaman serisi verilerini birlikte analiz etmeye olanak sağlayan pa-

5 Temel bileşenler analizi (Principal Component Analysis - PCA), geniş boyutlu bir veri kümesindeki yüksek korelasyonları tanımlayarak, herhangi bir önemli bilgi kaybı olmaksızın önemli ölçüde daha düşük boyutlu bir veri kümesinin oluşturulmasına olanak sağlayan bir boyut azaltma tekniğidir. Bu teknik, yeni bir matris sisteminde, veri kümesindeki en yüksek varyansa sahip değişkenin ilk koordinatta bulunması ve sonraki her değişkenin sonuncuya ortogonal olacak şekilde lineer dönüşümünün yapılarak yeni bir temel bileşen oluşturulması şeklinde uygulanır (Abdi ve Williams, 2010). Endeks değişkeni oluşturulmadan önce modelin uygunluğunu test etmek amacıyla Bartlett (1950) testi yapılmıştır. Test sonuçları değişkenler arasında bir ilişkinin var olduğu ve endeks oluşturmada bir sakınca olmadığı yönündedir.

6 Çalışmada kullanılan enflasyon oranı verileri IMF'den sağlanırken, diğer tüm değişkenlere ait veriler Dünya Bankası veri tabanından alınmıştır. 
nel veri modelleri yardımıyla araştırılmaktadır. Çalışmada, bağımsız değişkenler arasındaki çoklu doğrusal bağlantı probleminden kaçınmak için her bir kurumsal kalite değişkeni (KKD) modellere tek tek dahil edilmektedir. Bu değişkenlerin modellerde tek tek yer almasının yanı sıra kurumsal kalite göstergelerinin tümünün pay piyasası gelişimi üzerindeki etkisini ortaya koymak amacıyla temel bileşenler analizi yöntemi kullanılarak oluşturulan kurumsal kalite endeksi (KK) değişkeni de analize dahil edilerek yedi farklı panel veri modeli oluşturulmuştur. Bu bağlamda, MSCIEF ülkelerinde pay piyasasının gelişimine etki eden faktörleri saptamak için oluşturulan temel panel veri modeline ilişkin eşitlik aşağıdaki gibi ifade edilmektedir:

$$
\mathrm{PK}_{\mathrm{it}}=\beta_{1} \mathrm{KKD}_{\mathrm{it}}+\beta_{2} \mathrm{BO}_{\mathrm{it}}+\beta_{3} \mathrm{KRD}_{\mathrm{it}}+\beta_{4} \mathrm{DYY}_{\mathrm{it}}+\beta_{5} \mathrm{YIT}_{\mathrm{it}}+\beta_{6} \mathrm{YIY}_{\mathrm{it}}+\beta_{7} \mathrm{TUFE}_{\mathrm{it}}+\varepsilon_{\mathrm{it}}
$$

Eşitlik (1)'de bulunan tüm değişkenler Tablo 1'de açıklanmaktadır. Eşitlik (1)'de i birim boyutunu, t zaman boyutunu, $\varepsilon_{\text {it }}$ ise eşitliğin hata terimini temsil etmektedir. Modelin birim boyutu 25 ülkeden, zaman boyutu ise 2002-2017 yılları arasındaki 16 yıldan oluşmaktadır.

Çalışmada oluşturulan yedi modelde, panel veri modellerinden klasik, sabit etkiler ya da rassal etkiler tahmincilerinden hangisinin kullanılacağını belirlemek için $F$ testi ve Breusch-Pagan Lagrange Çarpanı testi kullanılmaktadır. Sabit etkiler ve rassal etkiler tahmincileri arasında seçim yapmak içinse, Hausman testine başvurulmaktadır. Panel veri modellerinin tahmin yöntemleri belirlendikten sonra, sıra modellerin temel varsayımlarının testine gelmektedir. Bu bağlamda, modellerde değiş̧en varyans, otokorelasyon ve birimler arası korelasyon testleri modelin sabit etkiler veya rassal etkiler modeli olmasına göre gerçekleştirilmektedir. Bu testlerde elde edilen sonuçlara göre, temel varsayımlardan sapan modellerde dirençli tahminciler kullanılmaktadır (Yerdelen Tatoğlu, 2012).

\section{Ampirik Bulgular}

Tablo 2'de araştırma kapsamında oluşturulan yedi farklı modelde yer alan değişkenlere ilişkin tanımlayıc istatistikler yer almaktadır. Modellerde bağımlı değişken olarak kullanılan piyasa kapitalizasyonun (PK) ortalaması 0,58'dir. Buna göre, 2002-2017 yılları arasında MSCIEF ülkelerinin pay piyasalarında işlem gören payların toplam piyasa değerlerinin, bu ülkelerin gayri safi yurtiçi hasılalarının yarısından daha fazla olduğunu görülmektedir. PK'nın minimum ve maksimum değerleri yaklaşık 0,07 ile 3,28 arasında değişmektedir. Bu değerler arasındaki fark, MSCIEF ülkelerinde pay piyasasının gelişiminin farklı düzeylerde olduğunu işaret etmektedir. Bir 
başka ifadeyle bazı ülkelerde işlem gören payların toplam piyasa değerleri GSYH'nin oldukça altındayken, diğerlerinde neredeyse üç katını geçmektedir. Dünya Bankası kaynaklarında da belirtildiği üzere kurumsal kalite değişkenleri yaklaşık olarak -2,5 ile $+2,5$ arasında değerler almaktadır (Kaufmann vd., 2010). Bu bağlamda, ülkelerin kurumsal kalite düzeyleri arttıkça KKD değişkenlerine ilişkin değerler $+2,5^{\prime}$ e, ülkelerin kurumsal kalite düzeyleri zayıfladıkçaysa bu değerler -2,5'e yaklaşmaktadır. Altı kurumsal kalite göstergesi ve temel bileşenler analizi yardımıyla oluşturulan kurumsal kalite endeksinin (KK) ortalaması ise O'dır. Bu değer, analize dahil edilen ülkelerin kurumsal kalite düzeylerinin zayıf olduğunu göstermektedir. Bu düzeyinin düşük seviyelerde olmasına en büyük katkıyı sırasıyla politik istikrar ve şiddetsizlik (PI), ifade özgülüğü ve hesap verebilirlik ( $\mathrm{OH}$ ) ile yolsuzluğun kontrolü (YK) değişkenlerinin neden olduğu düşünülmektedir. İncelenen dönemde bu değişkenlere ilişkin ortalama değerler de negatiftir (sırasıyla -0,332, -0,065 ve -0,039). KKD değişkenlerinden hükümetin etkinliği (HE) değişkeni ise 0,26 ile en yüksek ortalamaya sahiptir.

\section{Tablo 2. Değişkenlere ilişkin tanımlayıcı istatistikler}

\begin{tabular}{lccccc}
\hline Değişkenler & Gözlem sayısı & Ortalama & Standart sapma & Minimum değer & Maksimum değer \\
\hline PK & 391 & 0,581 & 0,474 & 0,065 & 3,284 \\
YK & 400 & $-0,039$ & 0,617 & $-1,144$ & 1,592 \\
HE & 400 & 0,264 & 0,548 & $-0,877$ & 1,510 \\
PI & 400 & $-0,332$ & 0,921 & $-2,810$ & 1,261 \\
DK & 399 & 0,261 & 0,595 & $-1,074$ & 1,539 \\
HU & 400 & 0,052 & 0,628 & $-0,970$ & 1,433 \\
IOH & 400 & $-0,065$ & 0,830 & $-1,907$ & 1,293 \\
KK & 399 & 0,000 & 0,969 & $-2,367$ & 2,619 \\
BO & 400 & 0,044 & 0,038 & $-0,109$ & 0,262 \\
KRD & 400 & 0,602 & 0,401 & 0,097 & 1,601 \\
DYY & 400 & 0,031 & 0,050 & $-0,158$ & 0,546 \\
YIT & 400 & 0,282 & 0,133 & 0,018 & 0,755 \\
YIY & 400 & 0,246 & 0,072 & 0,102 & 0,489 \\
TUFE & 397 & 0,050 & 0,046 & $-0,049$ & 0,451 \\
\hline
\end{tabular}

Modellerde bağımsız değişken olarak yer alan makroekonomik değişkenlerden doğrudan yabancı yatııımların (DYY) 0,03 ile en düşük ortalamaya, yurtiçi kredilerin (KRD) ise 0,60 ile en yüksek ortalamaya sahip olduğu görülmektedir. Tablo 2'ye göre MSCIEF ülkelerindeki GSYH büyüme oranları düşük seviyelerde seyretmektedir. GSYH büyüme oranının minimum ve maksimum değerleri yaklaşık olarak -0,11 ve 0,26 arasında değişmektedir. Buna istinaden bu ülkelerde GSYH büyüklüğünün Piyasalar Üzerine Bir Araştırma”, BDDK Bankacılık ve Finansal Piyasalar Dergisi, 15, (1), 2021, 147-173 
zaman zaman düşüşe geçtiğini söylemek mümkündür. Ayrıca Tablo 2, makroekonomik değişkenlerin, kurumsal kalite değişkenlerine (KKD) göre nispeten daha düşük standart sapmalara sahip olduğunu göstermektedir. Bu sonuç, kurumsal kalite değişkenlerinin incelenen dönemde daha fazla değişkenlik gösterdiğini ifade etmektedir.

Araştırmanın değişkenlerine ilişkin korelasyon analizi sonuçları ve varyans artış faktörü (Variance Inflation Factor - VIF) değerleri Tablo 3'te sunulmaktadır. Tablo 3 incelendiğinde, kurumsal kalite değişkenleri arasında oldukça yüksek pozitif korelasyonlar olduğu görülmektedir. Birçok KKD değişkeni için korelasyon katsayısı 0,80'inin üzerindedir. Bu sonuçtan hareketle, KKD'lerin regresyon modellerinde birlikte yer almasının çoklu doğrusal bağlantı problemine neden olabileceği söylenebilir. Literatürde regresyon modellerinde çoklu doğrusal bağlantı probleminin oluşup oluşmayacağını belirlemek için VIF değerlerine bakılmakta ve VIF değerlerinin 5'ten büyük olduğu durumlarda çoklu doğrusal bağlantı probleminin ortaya çıkabileceği ifade edilmektedir (Rogerson, 2001; Ringle, 2015; Garson, 2016; Sarstedt vd. 2017). Tablo 3'te KKD'lere ilişkin VIF değerlerinin çoğunun 5 'ten büyük olduğu görülmektedir. Bu nedenle çoklu doğrusal bağlantı probleminden kaçınmak için KKD'ler modellere tek tek dahil edilmektedir.

Tablo 3, ifade özgürlüğü ve hesap verilebilirlik $(\mathrm{IOH})$ değişkeni hariç, her bir kurumsal kalite değişkeninin piyasa kapitalizasyonu (PK) ile istatiksel olarak anlamlı pozitif ilişkiye sahip olduğunu göstermektedir. Makroekonomik değişkenler ile PK arasında da çoğunlukla istatiksel olarak anlamlı pozitif bir ilişki vardır. Buna göre, sadece doğrudan yabancı yatırım (DYY) ve enflasyon oranı (TUFE) değişkenlerinin piyasa kapitalizasyonu ile arasında negatif bir ilişkisi söz konusudur. Diğer taraftan bu ilişki, enflasyon oranı için istatiksel olarak anlamlı iken, doğrudan yabancı yatırımlar için anlamsızdır. 


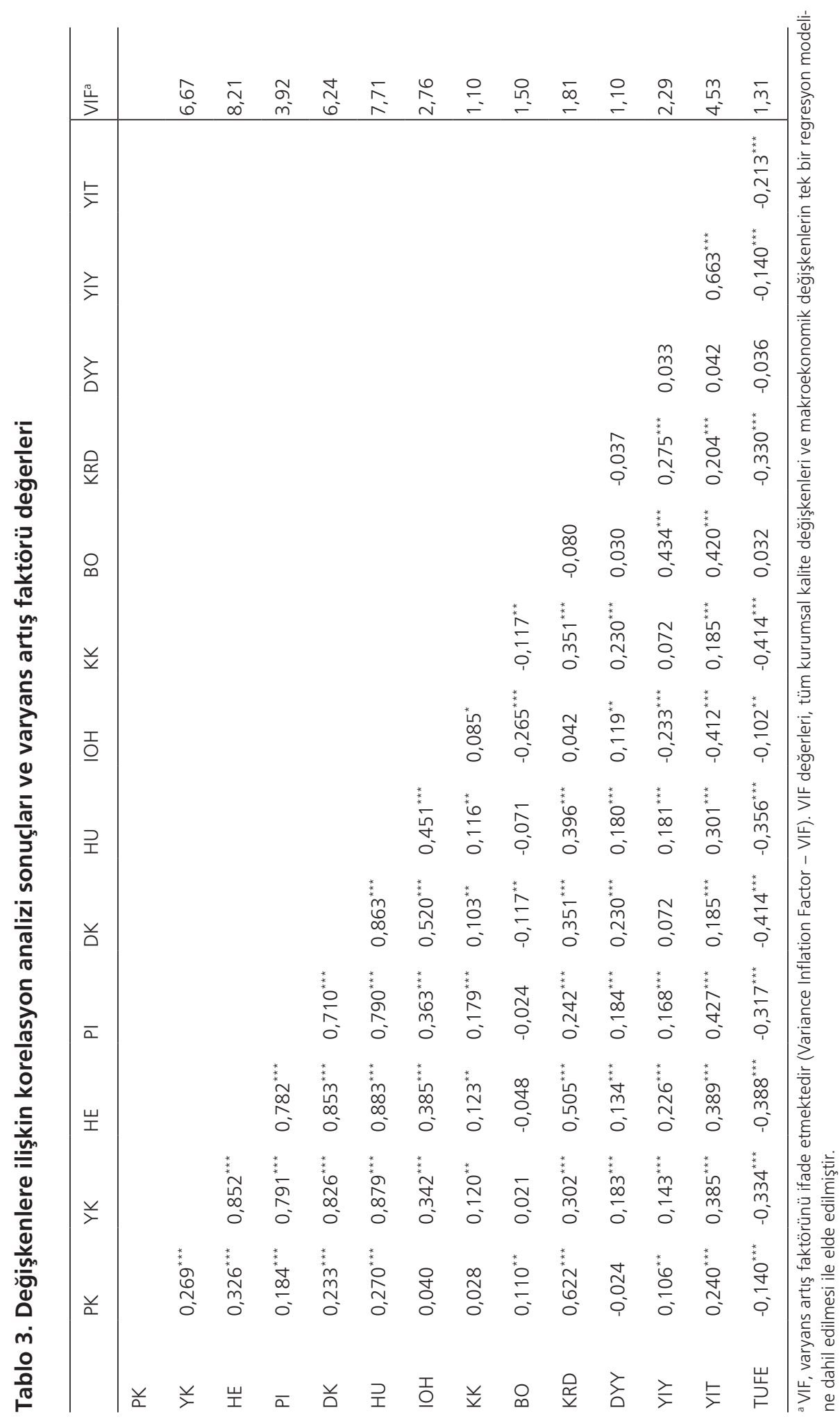


Tablo 4. Kurumsal ve makroekonomik faktörlerin pay piyasalarının gelişimine etkisi

\begin{tabular}{|c|c|c|c|c|c|c|c|}
\hline & Model 1 & Model 2 & Model 3 & Model 4 & Model 5 & Model 6 & Model 7 \\
\hline YK & $\begin{array}{l}-0,060 \\
{[0,117]}\end{array}$ & & & & & & \\
\hline HE & & $\begin{array}{l}0,001 \\
{[0,162]}\end{array}$ & & & & & \\
\hline Pi & & & $\begin{array}{l}0,070 \star \\
{[0,037]}\end{array}$ & & & & \\
\hline DK & & & & $\begin{array}{l}0,041 \\
{[0,162]}\end{array}$ & & & \\
\hline HU & & & & & $\begin{array}{l}0,097 \\
{[0,103]}\end{array}$ & & \\
\hline İOH & & & & & & $\begin{array}{l}0,222^{*} \\
{[0,123]}\end{array}$ & \\
\hline KK & & & & & & & $\begin{array}{l}0,018 \\
{[0.020]}\end{array}$ \\
\hline BO & $\begin{array}{l}0,677^{*} \\
{[0,380]}\end{array}$ & $\begin{array}{l}0,673 \\
{[0,418]}\end{array}$ & $\begin{array}{l}0,604 \\
{[0,369]}\end{array}$ & $\begin{array}{l}0,663^{*} \\
{[0,366]}\end{array}$ & $\begin{array}{l}0,726^{*} \\
{[0,396]}\end{array}$ & $\begin{array}{l}0,650^{*} \\
{[0,378]}\end{array}$ & $\begin{array}{l}0,629^{*} \\
{[0,347]}\end{array}$ \\
\hline KRD & $\begin{array}{l}0,308^{*} \\
{[0,168]}\end{array}$ & $\begin{array}{l}0,315^{*} \\
{[0,177]}\end{array}$ & $\begin{array}{l}0,316^{*} \\
{[0,162]}\end{array}$ & $\begin{array}{l}0,316^{*} \\
{[0,166]}\end{array}$ & $\begin{array}{l}0,306^{*} \\
{[0,165]}\end{array}$ & $\begin{array}{l}0,389^{* *} \\
{[0,159]}\end{array}$ & $\begin{array}{l}0,316^{*} \\
{[0,166]}\end{array}$ \\
\hline DYY & $\begin{array}{l}0,130 \\
{[0,138]}\end{array}$ & $\begin{array}{l}0,127 \\
{[0,137]}\end{array}$ & $\begin{array}{l}0,127 \\
{[0,136]}\end{array}$ & $\begin{array}{l}0,122 \\
{[0,138]}\end{array}$ & $\begin{array}{l}0,114 \\
{[0,144]}\end{array}$ & $\begin{array}{l}0,100 \\
{[0,132]}\end{array}$ & $\begin{array}{l}0,122 \\
{[0,141]}\end{array}$ \\
\hline Yíy & $\begin{array}{l}0,820 \\
{[0,561]}\end{array}$ & $\begin{array}{l}0,731 \\
{[0,561]}\end{array}$ & $\begin{array}{l}0,552 \\
{[0,524]}\end{array}$ & $\begin{array}{l}0,658 \\
{[0,578]}\end{array}$ & $\begin{array}{l}0,579 \\
{[0,477]}\end{array}$ & $\begin{array}{l}0,495 \\
{[0,527]}\end{array}$ & $\begin{array}{l}0,590 \\
{[0,571]}\end{array}$ \\
\hline Yіт & $\begin{array}{l}1,043^{* * *} \\
{[0,296]}\end{array}$ & $\begin{array}{l}1,037^{* *} \\
{[0,383]}\end{array}$ & $\begin{array}{l}0,932^{* * *} \\
{[0,287]}\end{array}$ & $\begin{array}{l}1,017^{* * *} \\
{[0,327]}\end{array}$ & $\begin{array}{l}0,980^{* * *} \\
{[0,305]}\end{array}$ & $\begin{array}{l}1,139^{* * *} \\
{[0,300]}\end{array}$ & $\begin{array}{l}0,968^{* * *} \\
{[0,361]}\end{array}$ \\
\hline TUFE & $\begin{array}{l}0,194 \\
{[0,220]}\end{array}$ & $\begin{array}{l}0,262 \\
{[0,226]}\end{array}$ & $\begin{array}{l}0,332 \\
{[0,237]}\end{array}$ & $\begin{array}{l}0,259 \\
{[0,246]}\end{array}$ & $\begin{array}{l}0,285 \\
{[0,237]}\end{array}$ & $\begin{array}{l}0,247 \\
{[0,245]}\end{array}$ & $\begin{array}{l}0,285 \\
{[0.237]}\end{array}$ \\
\hline Sabit & $-0,285$ & $-0,271$ & $-0,197$ & $-0,258$ & $-0,227$ & $-0,275^{\star}$ & $-0,234$ \\
\hline $\begin{array}{l}\text { Zaman } \\
\text { Etkisi }\end{array}$ & Var & Var & Var & Var & Var & Var & Var \\
\hline $\begin{array}{l}\text { Gözlem } \\
\text { Sayısı }\end{array}$ & 388 & 388 & 388 & 387 & 388 & 388 & 387 \\
\hline F testi & $53,04^{* * *}$ & $52,71^{* * *}$ & $52,76^{* * *}$ & $52,44^{* * *}$ & $52,61^{* * *}$ & $52,65^{\star \star *}$ & $52,39^{* * *}$ \\
\hline BP LM test & $1348,88^{* * *}$ & $1340,93^{* * *}$ & $1342,03^{* * *}$ & $1349,85^{* * *}$ & $1347,74^{* * *}$ & $1315,64^{* * *}$ & $1359,77^{* * *}$ \\
\hline $\begin{array}{l}\text { Hausman } \\
\text { testi }\end{array}$ & $24,12^{* * *}$ & $25,59^{* * *}$ & $30,62^{* * *}$ & $24,01^{* * *}$ & $27,24^{* * *}$ & $27,17^{* * *}$ & $27,82^{* * *}$ \\
\hline F İstatistiği & $137,84^{\star * *}$ & $64,230^{* * *}$ & $22,203^{* * *}$ & $55,668^{* * *}$ & $16,731^{* * *}$ & $19,702^{* * *}$ & $271,23^{* * *}$ \\
\hline $\mathbf{R}^{2}$ & 0,341 & 0,339 & 0,349 & 0,340 & 0,343 & 0,367 & 0,346 \\
\hline
\end{tabular}

***, ** , * sırasıyla \%1, \%5 ve \%10 düzeyinde istatiksel anlamlılı̆̆ı göstermektedir. Köşeli parantez içindeki değerler dirençli standart hataları göstermektedir.

E. Karpuz, N. Özkan, "Kurumsal Kalitenin ve Makroekonomik Göstergelerin Finansal Piyasalara Etkisi: Gelişmekte Olan Piyasalar Üzerine Bir Araştırma”, BDDK Bankacılık ve Finansal Piyasalar Dergisi, 15, (1), 2021, 147-173 
Tablo 4'te kurumsal kalite değişkenleri ile makroekonomik değişkenlerin MSCIEF ülkelerinin pay piyasasının gelişimine etkilerini gösteren modellere ait sonuçlar sunulmaktadır. Modellere ilişkin F testi ve BP LM testi sonuçları, modellerde klasik panel veri modelinin kullanılamayacağını işaret etmektedir. Sabit ve rassal etkiler modelleri arasında tercih yapabilmek için gerçekleştirilen Hausman testi sonuçları ise, regresyon modellerinde sabit etkiler modelinin kullanılmasının uygun olduğunu ortaya koymaktadır. Tüm bu testler sonucunda, pay piyasası gelişimine etki eden faktörleri saptamak için oluşturulan yedi model, iki yönlü sabit etkiler regresyon modeli ile tahmin edilmektedir. Sabit etkiler regresyon modellerinde uygulanan Pesaran (2004) testi sonuçlarına göre modellerde birimler arası korelasyonun olmadığı tespit edilmiştir. Modellerde değişen varyans, ve otokorelasyon problemlerini bertaraf etmek içinse, bu problemlere karşı dirençli standart hatalar kullanılmaktadır. Modellere ilişkin F istatistiği sonuçları, tüm modellerin \%1 düzeyinde istatiksel olarak anlamlı olduğunu göstermektedir. Modellerin pay piyasası gelişimini açıklama güçleri karşılaştııldığında ise, piyasa kapitalizasyonunu açıklayan en iyi modelin Model $6(R 2=0,367)$ olduğu görülmektedir.

Tablo 4, kurumsal kalite değişkenlerinin her birinin, MSCIEF ülkeleri pay piyasalarının gelişimi üzerinde farklı etkilerinin olduğunu göstermektedir. Model (1)'de kamu gücünün kişisel kazançlar elde etmek için ne ölçüde kullanıldığını ifade eden yolsuzluğun kontrolü (YK) ve Model (2)'de devletin politika oluşturma ve uygulama etkinliğini temsil eden hükümetinin etkinliği (HE) değişkenlerinin pay piyasalarının gelişimi üzerinde istatiksel olarak anlamlı bir etkisinin bulunmadığı görülmektedir. Elde edilen bulgular, Cherif ve Gazdar (2010)'un Orta Doğu ve Kuzey Afrika ülkeleri için elde ettiği sonuçları destekler niteliktedir. Buna karşın, literatürde farklı bakış açıları da bulunmaktadır. Yolsuzluğun önlenmesinin pay piyasalarını olumlu etkileyeceğini öne süren çok sayıda çalışma bulunurken (Asongu, 2012; Şahin ve Temelli, 2018; Ayaydın vd., 2020), yolsuzluğun firmaların ağır kamu politikalarından kaçınmasına yardımcı olduğunu ve dolayısıyla yolsuzluğun önlenmesinin olumsuz etkiye neden olduğunu ifade eden çalışmalar da bulunmaktadır (Dzhumashev, 2014; Thanh vd., 2016). Ayrıca literatürde, hükümetin etkinliği değişkeninin de pay piyasasının gelişimini pozitif etkileyeceği savunulmaktadır (Ajide, 2014; Thanh, 2016; Ayaydın vd. 2020).

Tablo 4 Model 3'te politik istikrar ve şiddetin yokluğu (PI) değişkeninin MSCIEF ülkelerinin pay piyasalarına etkisi sınanmaktadır. Ülkede terörizmi de içeren politik istikrarsızlığın ve şiddetin düşük seviyede olmasının pay piyasalarının gelişimini istatistiksel olarak \%10 anlamlılık düzeyinde pozitif etkilediği görülmektedir. Bu sonuç, li- 
teratürde terörizmin olmadığı ve siyasi istikrarın sağlandığı ülkelerde pay piyasası gelişiminin arttığını ileri süren çalışmalarla tutarlılık göstermektedir (Ayaydın vd., 2020; Yartey 2008; Boadi ve Amegbe, 2017). Ayrıca söz konusu ilişkiyi Asya ülkeleri için araştıran Gani ve Ngassam, (2008)'in bulgularını da destekler niteliktedir. Diğer yandan elde edilen bulgular, PI değişkeninin pay piyasalarının gelişimi üzerinde negatif etkili olduğunu ifade eden çalışmalarla çelişmektedir (Ajide, 2014; Thanh vd., 2016).

Yine Tablo 4'te görüleceği üzere Model (4) hükümetin politikaları uygulama yeterliliğini ölçen düzenleyici kalitesinin (DK) pay piyasalarının gelişimi üzerindeki etkisini incelerken; Model (5) ceza sisteminin ve mahkemelerin bağımsızlığını ölçen hukukun üstünlüğü $(H U)$ değişkeninin etkisini test etmektedir. Regresyon sonuçlarına göre, her iki değişkenin de pay piyasalarının gelişimine etkisi pozitiftir ancak bu etki istatiksel olarak anlamsızdır. Bu bulgular literatürde Law ve Azman-Saini (2008) ile Cherif ve Gazdar (2010)'un çalışmalarını desteklerken, diğer çalışmalarla zıtlık göstermektedir (Aduda vd., 2012, Asongu, 2012; Umar ve Nayan, 2018; Güvercin ve Gök, 2019; Ayaydın vd. 2020).

Bir ülkedeki vatandaşların hükümet seçimlerine ne ölçüde katıldığını ve özgür bir medyayı temsil eden ifade özgürlüğü ve hesap verilebilirlik $(\mathrm{IOH})$ değişkeninin $\mathrm{MSCl}$ EF ülkelerinde pay piyasalarının gelişimine etkisi Model $\sigma^{\prime}$ da incelenmektedir. Model sonuçlarına göre, ifade özgürlüğü ve hesap verilebilirlikte $(\mathrm{IOH})$ meydana gelen gelişmeler pay piyasası gelişimini \%10 anlamlılık düzeyinde pozitif etkilemektedir. Bu sonuç, literatürdeki pek çok çalışmayla paralellik göstermektedir (Law ve Azman-Saini, 2008; Asongu, 2012; Boadi ve Amegbe, 2017; Ayaydın vd., 2020). Öte yandan bulgular, birtakım çalışmalarla çelişmektedir (Ajide,2014; Thanh vd., 2016). Model 7'de ise farklı boyutları temsil eden her bir kurumsal kalite değişkeni (KKD) ile oluşturulan kurumsal kalite endeksinin (KK), MSCIEF ülkelerinde pay piyasalarının gelişimine olan etkisine bakılmaktadır. Modelde saptanan bulgulara göre, oluşturulan endeksin pay piyasaları gelişimine etkisi pozitif ancak istatiksel olarak anlamsızdır. Bulgularımız literatürde kurumsal kalite endekslerini pay piyasalarının gelişimi ile ilişkilendiren ve bu ilişkinin pozitif olduğunu savunan çalışmalarla zıtlık göstermektedir (Law ve Habibullah. 2009; Aduda vd., 2012: Law ve Azman-Saini, 2012).

Araştırmanın makroekonomik göstergeleri olan büyüme oranı (BO), yurtiçi krediler (KRD), doğrudan yabancı yatırımlar (DYY), yurtiçi tasarruflar (YIT), yurtiçi yatırımlar (YIY) ve enflasyon oranı (TUFE) değişkenleri tüm modellerde yer almaktadır. Tablo 4'te yer alan sonuçlara göre, büyüme oranının katsayıları tüm modellerde pozitiftir. Ancak bu katsayılar, sadece Model (2 ve 3) dışındaki diğer modellerde

E. Karpuz, N. Özkan, "Kurumsal Kalitenin ve Makroekonomik Göstergelerin Finansal Piyasalara Etkisi: Gelişmekte Olan Piyasalar Üzerine Bir Araştırma”, BDDK Bankacılık ve Finansal Piyasalar Dergisi, 15, (1), 2021, 147-173 
\%10 düzeyinde istatiksel olarak anlamlıdır. Bu sonuçlardan hareketle, MSCIEF ülkelerindeki ekonomik büyümenin az da olsa, şirketlerin piyasa kapitalizasyonunu artırıcı bir etkisinin olduğu ve piyasa gelişimini hızlandırdığı ifade edilebilir. Ayrıca, yurtiçi krediler değişkeni de Model (6)'da \%5 düzeyinde, diğer modellerde ise \%10 düzeyinde istatistiksel olarak anlamlı ve pozitiftir. Buna göre, finansal derinliğin banka temelli ölçütü olan özel sektöre verilen kredilerin GSYH içindeki payı arttıkça, pay piyasası kapitalizasyonunu da yükselmektedir. Elde edilen bu bulgular, literatürde artan ekonomik büyüme oranlarının ve özel sektöre verilen kredilerin pay piyasası gelişimini arttıracağını savunan çalışmaları kısmen desteklemektedir (Garcia ve Liu, 1999; Yartey, 2008; Cherif ve Gazdar, 2010; Shahbaz vd., 2015; Thanh vd., 2016).

Tablo 4'teki sonuçlar, gelişmekte olan ülkelere gelen doğrudan yabancı yatırımların (DYY) ve yurtiçi yatırımların (YIY) pay piyasalarının gelişimi üzerinde etkisi olmadığını göstermektedir. Bulgularımız Thanh vd., (2016)'nin bulguları ile paralellik gösterse de, diğer birçok çalışma (Garcia ve Liu, 1999; Claessens vd., 2001; Yartey, 2008; Ayaydın ve Baltacı, 2013; Raza vd., 2015, Shahbaz vd., 2015; Acquah-Sam, 2016) yerli ve yabanc yatırımları pay piyasalarının gelişimi ile ilişkilendirmekte ve bu ilişkinin pozitif olduğunu ileri sürmektedir. Ayrıca, araştırmada makroekonomik istikrarın göstergesi olan enflasyon oranında (TUFE) meydana gelen artış ekonomik oynaklığa sebep olacağından, yatırımcıların ve şirketlerin pay piyasalarına güvenini azaltacağı bu sebeple piyasa gelişimini negatif etkileyeceği beklenmiştir. Ancak beklentilerin aksine sonuçlar enflasyon oranının (TUFE) piyasa kapitalizasyonu üzerinde pozitif ancak istatiksel olarak anlamlı bir etkisinin olmadığını göstermektedir. Bulgularımız literatürdeki bazı çalışmaları desteklerken (Kemboi and Tarus, 2012; Aduda vd., 2012), söz konusu ilişkinin istatiksel olarak anlamlı ve negatif olduğunu saptayan çalışmalarla zıtlık göstermektedir (Claessens vd., 2001; Ayaydın ve Baltacı, 2013; Thanh vd., 2016).

Araştırma bulgularına göre, MSCIEF ülkelerinin pay piyasalarının gelişimine etki eden ve istatiksel olarak anlamlılık düzeyi en yüksek makroekonomik faktör, yurtiçi tasarruflardır. Tablo 4'te görüldüğü gibi, tüm modellerde ülke içi tasarruf oranları, piyasa kapitalizasyonu üzerinde istatiksel olarak anlamlı pozitif etkiye sahiptir. Bir başka ifadeyle gelişmekte olan ülkelerde yurtiçi tasarrufların GSYH içindeki payı arttıkça, pay piyasasının gelişimi de hızlanmaktadır. Elde edilen bulgular, literatürde pay piyasaları ile yurtiçi tasarruflar arasındaki ilişkinin pozitif olduğunu ifade eden diğer çalışmalarla da uyumludur (Garcia ve Liu, 1999; Yartey, 2008; Cherif ve Gazdar, 2010; Shahabz vd., 2013). 


\section{Sonuç ve Değerlendirme}

Bu çalışma, Morgan Stanley Capital International Gelişmekte Olan Piyasalar Endeksi'nde (MSCIEF) yer alan 25 ülkenin finansal piyasalarının gelişimine etki eden kurumsal ve makroekonomik faktörleri saptamayı amaçlamaktadır. Çalışmada, 2002-2017 dönemini kapsayan yıllık veri setleri kullanılarak sözü edilen etki panel veri analizi yardımıyla test edilmektedir. Çalışmanın bağımlı değişkeni piyasa kapitalizasyonudur. Çalışmada kullanılan bağımsız değişkenler ise, kurumsal kalite değişkenleri ve makroekonomik değişkenler olmak üzere ikiye ayrılmaktadır. Kurumsal kalite değişkenlerini, Dünya Bankası tarafından yayımlanan yolsuzluğun kontrolü, hükümetin etkinliği, politik istikrar ve şiddetsizlik, düzenleyici kalitesi, hukukun üstünlüğü ile ifade özgürlüğü ve hesap verilebilirlik olmak üzere altı temel gösterge oluşturmaktadır. Ayrıca, temel bileşenler analizi yardımıyla bu altı gösterge kullanılarak yazarlar tarafından oluşturulan kurumsal kalite endeksi de çalışmanın diğer bir kurumsal kalite değişkenidir. Çalışmanın makroekonomik değişkenlerini ise, GSYH yıllık büyüme oranı, özel sektöre verilen krediler, doğrudan yabancı yatırımlar, yurtiçi yatırımlar, yurtiçi tasarruflar ve enflasyon oranı oluşturmaktadır.

Gelişmiş finansal piyasaların, ülkelerin ekonomik gelişimi ve kalkınması üzerinde oynadığı pozitif rol göz önünde bulundurulduğunda, finansal piyasaların gelişimini etkileyen faktörlerin saptanması önem arz etmektedir. Günümüzde finansal piyasalardaki gelişimi etkileyen bu faktörlerin sadece makroekonomik koşulları değil; aynı zamanda ülkelerdeki politik, yasal ve kurumsal çerçeveleri de içinde barındırdığı ileri sürülmektedir (Thanh vd., 2016; Ajide, 2014; Law ve Azman-Saini, 2012; Asongu, 2012; Yartey, 2008). Bu bağlamda çalışma, MSCIEF'te yer alan ülkelerdeki finansal piyasaların gelişimini etkileyen faktörlerin, ülkelerin ekonomik faaliyetleriyle sınırlı kalmadığına, kurumsal kalite göstergelerinin de bu gelişimi etkileyebileceğine dair ampirik bulgular ortaya koymaktadır.

Çalışmada elde edilen bulgulara göre, altı kurumsal kalite göstergesinin ve makroekonomik faktörlerin MSCIEF'te yer alan ülkelerin pay piyasalarının gelişimi üzerindeki etkileri farklılık göstermektedir. Bulgularda, kurumsal kalite göstergelerinden politik istikrarsızlığın ve şiddetin azaltılmasının, finansal piyasaların gelişimine olumlu bir etkisinin olduğu saptanmıştır. Ayrıca, çalışmada gelişmekte olan ülke vatandaşlarının ifade özgürlüğünün sağlanmasının ve hükümetlerin faaliyetlerinde şeffaf ve hesap verebilir hale gelmesinin de bu ülkelerin finansal piyasalarındaki gelişmeleri pozitif etkilediği görülmektedir. Buna karşın, incelenen dönemde ülkelerdeki yolsuzluğun kontrolü, hükümetin politika uygulamadaki etkinliği, düzenleyici kurumların kalitesi,

E. Karpuz, N. Özkan, "Kurumsal Kalitenin ve Makroekonomik Göstergelerin Finansal Piyasalara Etkisi: Gelişmekte Olan Piyasalar Üzerine Bir Araştırma”, BDDK Bankacılık ve Finansal Piyasalar Dergisi, 15, (1), 2021, 147-173 
hukukun üstünlüğü ve kurumsal kalite endeksi gibi göstergelerin araştırmaya dahil edilen ülkelerin finansal piyasalarının gelişimi üzerinde istatiksel olarak etkili olmadığı bulunmuştur. Çalışmanın makroekonomik değişkenlerine ilişkin bulgulara bakıldığında ise, finansal piyasaların gelişimine etki eden en önemli faktörün, yurtiçi tasarruflar olduğu sonucuna ulaşılmaktadır. Buradan hareketle, gelişmekte olan ülkelerde yatırımların en önemli finansman kaynaklarından biri olan yurtiçi tasarruflarda meydana gelen artışın, finansal piyasaların gelişimine öncülük ettiğini söylemek mümkündür. Makroekonomik değişkenlere ilişkin bir diğer bulgu, finansal derinliğin banka temelli ölçütü olan özel sektöre verilen kredilerdeki artışın, finansal piyasaların gelişimi üzerinde pozitif etkili olduğudur. Buna göre, MSCIEF'te yer alan ülkelerde yurtiçi kredilerde meydana gelen iyileşmelerin, bankacılık sektörü ve pay piyasaları arasında tamamlayıcı bir ilişki kurulmasına olanak sağladığı ve pay piyasalarının gelişimini desteklediği söylenebilir. Ekonomik büyümenin en önemli göstergesi olan GSYH yıllık büyüme oranındaki artış ise, pay piyasalarının gelişimi üzerinde pozitif etkili olan bir diğer makroekonomik değişkendir. Bulgulara ek olarak çalışmada, doğrudan yabancı yatıımlar, yurtiçi yatııılar ve enflasyon oranının MSCIEF'te yer alan ülkelerin pay piyasalarının gelişimi üzerinde etkili olmadığı sonucuna ulaşılmışır.

Çalışmanın, politika yapııılara finansal piyasaların gelişimini etkileyen temel faktörlerin farkına varmaları hususunda fikir vermesi beklenmektedir. Bu bağlamda, çaıışma finansal piyasaların gelişimi hızlandıracak makroekonomik ve kurumsal koşulları iyileştirmede politika uygulayııılara destek olacaktır. Yapısal reformların her daim gündemde olduğu birçok gelişmekte olan ülkedeki politika yapııılar ve karar vericiler için şu öneriler verilebilir: (i) ülkede şeffaf, öngörülebilir ve hesap verilebilir bir kurumsal yönetimin anlayışının hakim kıınması, (ii) ifade özgürlüğünü koruyucu ve arttıııcı hukuki düzenlemelerin yapılması, (iii) ülkedeki siyasi iradenin politik istikrarı bozucu ve ülkede şiddet ortamını yaratacak söylem ve uygulamalardan uzak durması, (iv) özel sektöre uygun maliyetlerle verilen kredilerin verimli alanlarda kullanılmasının teşvik edilmesi ve böylece şirketlerin büyüyüp gelişmelerine katkıda bulunulması, (v) kredi maliyetlerinin azaltılması için yurtiçi tasarrufların arttııımasını özendirici uygulamaların geliştirilmesi ile burada oluşacak fonların finansal piyasalara ve rekabet avantajı yaratacak verimli alanlara yönlendirilmesi, (vi) ülkenin reel büyüme oranlarını istikrarlı düzeyde tutacak politikaların geliştirilerek uygulanması.

Çalışmanın, literatüre katkılarının yanı sıra barındırdığı çeşitli kısıtlar da bulunmaktadır. Çalışmanın veri setinin 2002-2017 yıllarını kapsaması, veri setine sadece MSCIEF'te yer alan ülkelerin dahil edilmesi, modellerde tek bir bağımlı değişkenin kullanılması ve panel veri modellerinden yalnızca sabit etkiler modelinin kullanılması Piyasalar Üzerine Bir Araştırma”, BDDK Bankacılık ve Finansal Piyasalar Dergisi, 15, (1), 2021, 147-173 
çalışmanın barındırdığı kısıtlardandır. Bu bağlamda çalışma, gelecekteki araştırmalar için birtakım öneriler sunmaktadır. Gelecekteki çalışmalar, daha geniş bir veri seti ile farklı ülke gruplarıı da araştırmalarına dahil edebilir. Bunun yanı sıra, finansal piyasaların gelişimini temsil eden farklı değişkenler (işlem gören payların toplam piyasa değeri, kişi başına kote edilen şirket sayısı vb.) kullanılarak söz konusu ilişki farklı ekonometrik analiz modelleri (rassal etkiler modeli, dinamik panel veri modelleri vb.) ile incelenebilir. 


\section{Kaynakça}

1. Abdi, H, ve Williams, L, J, (2010), Principal component analysis, Principal Component Analysis, 2, 433-459, https://doi,org/10,1002/wics, 101

2. Acquah-Sam, E. (2016). Determinants Of Capital Market Development In Ghana. European Scientific Journal, ESJ, 12(1), 251. https://doi.org/10.19044/ esj.2016.v12n1p251

3. Aduda, J., Masila, J. M., ve Onsongo, E. N. (2012). The Determinants of Stock Market Development : The Case for the Nairobi Stock Exchange. International Journal of Humanities and Social Science, 2(9), 214-230.

4. Ajide, K. B. (2014). Quality of Governance and Stock Market Performance: The Nigerian Experience. Journal of Economics and Development Studies, 2(2), 501-522.

5. Asongu, S. A. (2012). Government Quality Determinants of Stock Market Performance in African Countries. Journal of African Business, 13(3), 183199. https://doi.org/10.1080/15228916.2012.727744

6. Ayaydın, H., ve Baltacı, N. (2013). Corruption, banking sector, and stock market develop- ment: A panel data analysis. European Jour- nal of Research on Education, Special Issue: Human Resource Management, 94-99.

7. Ayaydın, H., Barut, A., ve Pala, F. (2019). Farklı Gelişmişlik Düzeylerinde Kurumsal Kalitenin Borsa Performansı Üzerindeki Etkisi: Ampirik Bir Analiz. Uluslararası İktisadi ve Idari İncelemeler Dergisi, 22, 107-122. https://doi. org/10.18092/ulikidince.414985

8. Bartlett, M.S. (1950). Tests of Significance in Factor Analysis. British Journal of Statistical Psychology, 3, 77-85. https://doi.org/10.1111/j.2044-8317.1950. tb00285.x

9. Boadi, I., ve Amegbe, H. (2017). The Link between Quality of Governance and Stock Market Performance: International Level Evidence. European Journal of Government and Economics, 6(1), 78-101. https://doi.org/10.17979/ ejge.2017.6.1.4324

10. Cherif, M., ve Gazdar, K. (2010). Institutional and Macroeconomic Determinants of Stock Market Development in Mena Region: New Results From a 
Panel Data Analysis. The International Journal of Banking and Finance, 7(1), 139-159.

11. Claessens, S., Klingebiel, D., ve Schmukler, S. (2001). FDI and stock market development: Complements or substitutes? World Bank Working Paper.

12. Garcia, V. F., ve Liu, L. (1999). Macroeconomic Determinants of Stock Market Development. Journal of Applied Economics, 2(1), 29-59.

13. Garson, G. David. 2016. Partial Least Squares (PLS-SEM): 2016 Edition. Statistical Associates Publishing, Asheboro.

14. Güvercin, D. ve Gök, A. (2019). Institutions, Financial Development and Economic Growth. Dumlupınar Üniversitesi Sosyal Bilimler Dergisi. 124-141.

15. International Monetary Fund (IMF). External Relations Dept., . (1996). Stock Markets: A Spur to Economic Growth. In Finance ve Development, March 1996. USA: INTER NATIONAL MONETARY FUND. doi: https://doi. org/10.5089/9781451953190.022

16. İltaş, Y., ve Üçler, G. (2019). Kurumsal Kalite ve Finansal Riskin Menkul Kıymetler Borsası Üzerine Etkisi: Türkiye İçin Ampirik Bir İnceleme. Sosyoekonomi, 27(41), 113-128. https://doi.org/10.17233/sosyoekonomi.2019.03.06

17. Karaca, O. (2012). Finansal Gelişme ve Ekonomik Büyüme: Türkiye İçin Bir Nedensellik Analizi. BDDK Bankacılık ve Finansal Piyasalar, 6(2), 2012, 85- 111.

18. Kaufmann, D., Kraay, A., ve Mastruzzi, M. (2010). The Worldwide Governance Indicators: Methodology and Analytical Issues. In World Bank Policy Research Working Paper. www.govindicators.org.

19. Kemboi, J. K., ve Tarus, D. K. (2012). Macroeconomic Determinants of Stock Market Development in Emerging Markets: Evidence from Kenya. Research Journal of Finance and Accounting, 3(5), 57-69.

20. Khan, M.A., Kong, D., Xiang, J. ve Zhang, J., (2019). Impact of institutional quality on financial development: cross-country evidence based on emerging and growth-leading economies. Emerg. Mark. Finance Trade, 1-17. http:// dx.doi.org/10.1080/1540496X.2019.1588725.

21. Law, S. H. ve Azman-Saini, W. N. W. (2008). The Quality of Institutions and Financial Development, MPRA Paper No. 12107, posted 12. 
22. Law, S. H., ve Azman-Saini, W. N. W. (2012). Institutional Quality, Governance, and Financial Development. Economics of Governance, 13, 217-236.

23. Law, S. H., ve Habibullah, M. S. (2009). The Determinants of Financial Development: Institutions, Openness and Financial Liberalisation. South African Journal of Economics, 77(1), 45-58. https://doi.org/10.1111/j.18136982.2009.01201.x

24. Lombardo, D., ve Pagano, M. (2000). Legal Determinants of the Return on Equity. Centre for Studies in Economics and Finance Working Paper, 24.

25. Narayan, P. K., Sharma, S. S., ve Thuraisamy, K. S. (2015). Can governance quality predict stock market returns? New global evidence. Pacific Basin Finance Journal, 35, 367-380.

26. Pesaran, M. H., (2004). General Diagnostic Tests for Cross Section Dependence in Panels. University of Cambridge, Faculty of Economics, Cambridge Working Papers in Economic, 0435.

27. Raza, A., Iqbal, N., Zeshan, A., Ahmed, M., ve Ahmed, T. (2012). The Role of FDI on Stock Market Development: The Case of Pakistan. Journal of Economics and Behavioral Studies, 4(1), 26-33. https://doi.org/10.22610/jebs. v4i1.299

28. Ringle, Christian M., Wende, Sven, \& Becker, Jan-Michael. (2015). SmartPLS 3. Bönningstedt: SmartPLS.

29. Rogerson, P.A. (2001). Statistical Methods for Geography. London: Sage. https://dx.doi.org/10.4135/9781849209953

30. Sarstedt, M., Ringle, C. M., \& Hair, J. F. (2017). Partial least squares structural equation modelling. In: C. Homburg, et al. (Eds.), Handbook of market research (pp. 1-40). Springer International Publishing AG. https://doi. org/10.1007/978-3-319-05542-8_15-1

31. Shahbaz, M., Rehman, I. U., ve Afza, T. (2016). Macroeconomic Determinants of Stock Market Capitalization in an Emerging Market: Fresh Evidence from Cointegration with Unknown Structural Breaks. Macroeconomics and Finance in Emerging Market Economies, 9(1), 75-99. https://doi.org/10.10 $80 / 17520843.2015 .1053820$ Piyasalar Üzerine Bir Araştırma”, BDDK Bankacılık ve Finansal Piyasalar Dergisi, 15, (1), 2021, 147-173 
32. Şahin, D., ve Temelli, F. (2018). APEC Ülkelerinde Hisse Senedi Piyasası Gelişimin Makroekonomik ve Kurumsal Belirleyicileri Üzerine Bir Analiz. Uluslararası Iktisadi ve İdari İncelemeler Dergisi, Prof. Dr. Harun Terzi Özel Sayısı, 257-270.

33. Thanh, S. D., Hoai, B. T. M., ve Bon, N. VAN. (2016). Determinants of Stock Market Development: The Case of Developing Countries and Vietnam. Journal of Economics Development, 24(1), 32-53. https://doi.org/10.24311/ jed/2017.24.1.05

34. Umar, B., ve Nayan, S. (2018). Does Regulatory Quality Matters for Stock Market Development? Evidence from Africa. International Journal of Economics and Financial Issues, 8(4), 10-15.

35. Yartey, C. A. (2008). The Determinants of Stock Market Development in Emerging Economies: Is South Africa Different? IMF Working Paper, 8(32), 1.

36. Yerdelen Tatoğlu, F (2012). Panel Veri Ekonometrisi, 2nd Ed.; Beta Yayınevi: Istanbul, Turkey.

37. Winful, E. C., Sarpong, D., ve Agyei-Ntiamoah, J. (2016). Relationship between institutional quality and stock market performance: Evidence from emerging economies. African Journal of Business Management, 10(19), 469-484. 